7. Reprod. Fert. (1970) 22, 41-47

\title{
OVULATION INDUCED BY GONADOTROPHINS IN THE MARSUPIAL, SMINTHOPSIS CRASSICAUDATA (GOULD)
}

\author{
MEREDITH J. SMITH AND GILLIAN K. GODFREY* \\ Department of Zoology, University of Adelaide, \\ Adelaide, South Australia
}

(Received 29th March 1969, revised 16th June 1969)

\begin{abstract}
Summary. Injection of HCG into mature, female $S$. crassicaudata induced ovulation in three of six animals, whereas injection of PMSG or of PMSG followed after $48 \mathrm{hr}$ by HGG induced ovulation in all of seventeen females. Seven mated but none littered.

Ten adult females were injected with PMSG and HGG at the end of an induced oestrous cycle, when the corpora lutea were degenerate. Six mated but none littered. Of eight young females injected with PMSG and HCG, four mated but again none littered. All ova recovered after induced ovulation were unfertilized.

The number of ova released at induced ovulation was higher than in untreated animals and many unruptured follicles became luteinized. Ova were retained in the oviducts for longer than normal.
\end{abstract}

\section{INTRODUCTION}

The fat-tailed marsupial mouse, Sminthopsis crassicaudata (Gould), is a small dasyurid, the head and body measuring about $9 \mathrm{~cm}$ and the tail about $5 \mathrm{~cm}$ (Ewer, 1968). The species is widely distributed in Australia, the range extending over south-western Western Australia, South Australia, Victoria, New South Wales and into southern Queensland (Marlow, 1965). A colony has been maintained under laboratory conditions at the University of Adelaide for several years (Ewer, 1968; Martin, 1965).

$S$. crassicaudata is poly-oestrous and litters have been produced in every month of the year. However, $88 \%$ of the litters were born from July to January inclusive (combined data of Ewer, 1968; Martin, 1965; Godfrey, unpublished). A few females reared three successive litters, but many underwent long periods without giving birth, even though they were paired continuously with a fertile male. Some non-lactating females maintained more-or-less regular oestrous cycles; many were anoestrous (Godfrey, unpublished). One female gave birth when $18 \frac{1}{2}$ weeks old, but others were 14 months old before becoming pregnant, and some never bred (Ewer, 1968).

Godfrey (1969) found that oestrus in a closely-related species, S. larapinta,

* Present address: Chicago Zoological Park, Brookfield, Illinois 60513, U.S.A. 
could be detected by a high concentration of epithelial cells in the urine, such cells being virtually absent except in the oestrous and post-oestrous phases of the cycle. Ovulation occurs about a day after oestrus and is independent of copulation in $S$. crassicaudata (Godfrey, unpublished), as it is in other marsupials (Sharman, 1959).

Changes in the pouch at the expected time of parturition are similar in pregnant and non-pregnant marsupials (Sharman, 1962). Godfrey (unpublished) found that at about 12 days after mating in S. crassicaudata, the lips of the pouch become swollen and turgid; subsequently the floor of the pouch becomes vascular and granular in appearance. If no young are produced, the lips of the pouch become loose and flabby about 14 days post coitum.

An attempt was made to increase the reproductive efficiency of the colony by inducing ovulation, mating and pregnancy with gonadotrophic hormones. The results are reported here.

\section{MATERIALS AND METHODS}

\section{Animals}

The colony consisted of animals collected from the south-east of South Australia (near Millicent), from the upper Eyre Peninsula of South Australia (Warramboo) and from Birdsville in southern Queensland, together with progeny of matings in the laboratory of animals from within and between these populations. The animals were housed in galvanized iron and mesh cages provided with a wooden nest-box (Martin, 1965). Lighting was by daylight and room temperature was held at $70^{\circ} \mathrm{F}$. Feeds of minced beef heart supplemented with vitamins and calcium diphosphate were given on 5 nights a week and roughly-chopped, hard-boiled egg was provided on the remaining 2 nights (Godfrey, unpublished). Mealworms (Tenebrio larvae) were provided occasionally.

Young females were caged with their female littermates until they were 18 weeks old, when they were paired with an adult male. Non-lactating adult females were paired continuously with a male. Numerous spermatozoa were seen in the urine of all males used in the experiments.

Selection of animals for experimental treatments was not random. Where possible, littermates were assigned to different treatments. At the time of injection, young females weighed between 10.5 and $12.5 \mathrm{~g}$ and adult females between 12.5 and $17.5 \mathrm{~g}$.

The experiments were carried out in the months of October, November, December and January.

\section{Hormone preparations}

Gonadotrophin from pregnant mares' serum (PMSG) (Primantron, Schering) and human chorionic gonadotrophin (HCG) (Primogonyl, Schering) were dissolved in sterile normal saline a few minutes before injection. Control animals were injected with sterile normal saline. All injections were intraperitoneal, the volume injected varying between 0.05 and $0.2 \mathrm{ml}$. 
Observations on live females

Each morning for about 12 days after the first injection, the pouch condition of each female was noted, and a drop of urine was collected on a microscope slide and examined for the presence of epithelial cells and spermatozoa. From the 12th day, pouch condition only was noted.

\section{Histology}

A few females were killed with ether. The reproductive system was removed immediately and fixed for $24 \mathrm{hr}$ in alcohol-formalin-acetic acid before transfer to $80 \%$ alcohol for storage. Ovaries (with oviduct) and one uterus of each system were embedded in Paraplast (Fisher Scientific) and serial sections, cut at $8 \mu$, were stained with Ehrlich's haematoxylin and eosin. The remaining uterus was dissected and searched for ova under a dissecting microscope. Diameters of corpora lutea (CL) were calculated from the number of sections in which they appeared.

\section{RESULTS}

(a) Adult females in unknown reproductive state

(i) $H C G$ alone. Six females were given a single injection of HGG $(2.5,5.0$ or $10 \cdot 0$ i.u.). The two injected with $2 \cdot 5$ i.u. produced epithelial cells in the urine 3 days after the injection and their pouches became swollen and granular 15 to 16 days after injection. Three animals (injected with 5 or 10 i.u.) gave no sign of oestrus and their pouches remained small and hairy.

The sixth animal, injected with 10.0 i.u., was killed 5 days after injection. The ovaries contained twelve large, degenerating CL, nine newly-formed CL (average diameter $376 \mu$ ) and many large, luteinized follicles. The uterine glands were small, but well-coiled. Many nuclei of gland cells were undergoing mitosis.

(ii) PMSG alone. Four adult females were given a single injection of PMSG (20 i.u.). Epithelial cells appeared in the urine 5 to 7 days later, and two animals mated on the 3 rd and 5 th day respectively.

The ovaries of one mated animal killed on Day 6 contained thirteen large, degenerating CL (average diameter 674 $\mu$ ) and numerous tertiary follicles. The pouches of the remaining animals underwent pre-parturition changes and became flabby on the 20th day, suggesting that the two unmated animals underwent a 'silent' oestrus on Day 6, and ovulated on Day 7.

(iii) PMSG and HCG. Fourteen adult females were injected with PMSG $(20,10$, 5 or 2.5 i.u.), followed $48 \mathrm{hr}$ later by an injection of HCG ( 5 or 2.5 i.u.). All responded similarly, irrespective of the dose of hormone they received. Epithelial cells appeared in the urine on the 3rd to 10th day after PMSG, and five animals mated on the 3 rd (two animals), 4th, 6th and 10th days, resqectively. All pouches underwent pre-parturition changes 14 to 20 days after PMSG and became flabby on about the 20th day. No litters were born.

Three females were killed. All had ovulated (Table 1). Despite the presence of numerous spermatozoa in the oviducts of G196, the eggs were unfertilized. 
(b) Adult females injected 28 days after induced oestrus

The presence of GL in the ovaries, and possibly a luteal phase in the uteri of some females treated in (a) above, may have inhibited a full oestrous response to the injected gonadotrophins. To test the possibility that animals would be more responsive if treated when there was no functional luteal tissue in their ovaries, fifteen females were injected 28 days after the hormone-induced oestrus.

Examination of C330, killed on Day 0 of the second injection series confirmed

TABLE 1

TOTAL NUMBER AND SIZE OF CL, AND LOCATION OF OVA IN ADULT FEMALES TREATED WITH PMSG AND HCG

\begin{tabular}{|c|c|c|c|c|c|c|c|c|}
\hline \multirow{2}{*}{ Animals } & \multicolumn{2}{|c|}{ Treatments } & \multirow{2}{*}{$\begin{array}{c}\text { Day } \\
\text { killed }\end{array}$} & \multicolumn{3}{|c|}{$C L$ (both ovaries) } & \multirow{2}{*}{$\begin{array}{l}\text { Ova in } \\
\text { oviducts }\end{array}$} & \multirow{2}{*}{$\begin{array}{c}\text { Ova in } \\
\text { uteri }\end{array}$} \\
\hline & $P M S G(i . u)$. & $H C G(i . u)$. & & Total & $\begin{array}{l}\text { Av. diam. } \\
(\mu)\end{array}$ & $S . D$. & & \\
\hline C196 & 20 & 5 & 9 & 13 & $\begin{array}{c}299 \\
(n=5)\end{array}$ & 44 & 11 & 0 \\
\hline $\begin{array}{l}\text { C321 } \\
\text { C2207 }\end{array}$ & $\begin{array}{l}10 \\
20\end{array}$ & $\begin{array}{l}2 \cdot 5 \\
5\end{array}$ & $\begin{array}{l}10 \\
16\end{array}$ & $\begin{array}{l}17 \\
56\end{array}$ & $\begin{array}{l}732 \\
614\end{array}$ & $\begin{array}{r}71 \\
118\end{array}$ & $\begin{array}{l}0 \\
0\end{array}$ & $\begin{array}{r}15 \\
0\end{array}$ \\
\hline
\end{tabular}

TABLE 2

TOTAL NUMBER AND SIZE OF CL, AND LOCATION OF OVA IN ADULT FEMALES TREATED WITH PMSG AND HCG 28 DAYS AFTER AN INDUGED OESTRUS

\begin{tabular}{|c|c|c|c|c|c|c|c|c|}
\hline \multirow{2}{*}{ Animal } & \multicolumn{2}{|c|}{ Treatments } & \multirow{2}{*}{$\begin{array}{c}\text { Day } \\
\text { killed }\end{array}$} & \multicolumn{3}{|c|}{$C L$ (both ovaries) } & \multirow{2}{*}{$\begin{array}{l}\text { Ova in } \\
\text { oviducts }\end{array}$} & \multirow{2}{*}{$\begin{array}{c}\text { Ova in } \\
\text { uteri }\end{array}$} \\
\hline & $P M S G(i . u)$. & $H C G$ (i.u.) & & Total & $\begin{array}{l}\text { Av. diam. } \\
(\mu)\end{array}$ & S.D. & & \\
\hline $\begin{array}{l}\text { C148 } \\
\text { C258 } \\
\text { C276 } \\
\text { Ci328 }\end{array}$ & $\begin{array}{r}0 \\
20 \\
10 \\
10\end{array}$ & $\begin{array}{l}0 \\
5 \\
5 \\
5\end{array}$ & $\begin{array}{r}9 \\
9 \\
12 \\
19\end{array}$ & $\begin{array}{l}\overline{25} \\
31 \\
62\end{array}$ & $\begin{array}{l}\overline{497} \\
737 \\
757\end{array}$ & $\begin{array}{l}\overline{27} \\
95 \\
23\end{array}$ & $\begin{array}{r}- \\
15 \\
10 \\
0\end{array}$ & $\begin{array}{l}\overline{7} \\
0 \\
0\end{array}$ \\
\hline
\end{tabular}

that the CL were degenerate, with vacuolated cells and pycnotic nuclei. The uteri were small, the endometrium consisting of small, scattered glands in a dense stroma.

Ten females were injected with PMsG (20 or 10 i.u.) followed $48 \mathrm{hr}$ later by HCG (5 i.u.). Five control females were injected with an equivalent volume of saline.

Epithelial cells appeared from 3 to 5 days after PMSG in the urine of all animals injected with hormone and persisted for several days. Six animals mated on Days 3 (four animals), 6 and 10, respectively. All pouches underwent pre-parturition changes between Days 14 and 19 and became flabby on about Day 20, suggesting that 'silent' oestrus had occurred on about Day 6, with ovulation on Day 7.

The animals injected with saline did not produce epithelial cells in the urine, nor did their pouches undergo any visible changes. 
Ovaries and uteri of one control (G148) on Day 9 resembled those of C330 killed on Day 0. At autopsy, three animals injected with hormone were seen to have ovulated (Table 2) but all the eggs recovered were unfertilized, although C276 and C328 were known to have mated. In addition to CL, the ovaries contained as many as twenty-one (C258) luteinized follicles which were indistinguishable from CL except for the degenerate ovum contained in them.

The uteri of all three experimental animals were enlarged, the uterine glands were well-coiled, and in C276 and C328 the gland cells were tall with nuclei mainly basal. The uterine lumen and many of the large glands of C328 were filled with polymorphonuclear leucocytes.

(c) Females treated when 22 to 24 weeks old

Usually females are at least 25 weeks old at their first oestrus (Godfrey, unpublished) though one animal did become pregnant when only 17 weeks

TABLE 3

TOTAL NUMBER AND SIZE OF CL, AND LOGATION OF OVA IN YOUNG FEMALES TREATED WITH PMSG AND HCG

\begin{tabular}{|c|c|c|c|c|c|c|c|c|}
\hline \multirow{2}{*}{ Animal } & \multicolumn{2}{|c|}{ Treatment } & \multirow{2}{*}{$\begin{array}{c}\text { Day } \\
\text { killed }\end{array}$} & \multicolumn{3}{|c|}{$C L$ (both ovaries) } & \multirow{2}{*}{$\begin{array}{l}\text { Ova in } \\
\text { oviducts }\end{array}$} & \multirow{2}{*}{$\begin{array}{l}\text { Ova in } \\
\text { uteri }\end{array}$} \\
\hline & $P M S G(i . u)$. & $H C G(i . u)$. & & Total & $\begin{array}{c}\text { Av. diam. } \\
(\mu)\end{array}$ & S.D. & & \\
\hline C352* & 0 & 0 & 9 & 11 & 628 & 66 & 0 & $\begin{array}{c}11 \\
\text { (blasto- } \\
\text { cysts) }\end{array}$ \\
\hline $\begin{array}{l}\text { C359 } \\
\text { C353 } \\
\text { C360 } \\
\text { C358 } \\
\text { C361 }\end{array}$ & $\begin{array}{c}0 \\
5 \\
5 \\
5+2 \cdot 5 \\
5+2 \cdot 5\end{array}$ & $\begin{array}{l}0 \\
2 \cdot 5 \\
2 \cdot 5 \\
2 \cdot 5 \\
2 \cdot 5\end{array}$ & $\begin{array}{r}14 \\
9 \\
14 \\
9 \\
14\end{array}$ & $\begin{array}{l}\overline{28} \\
30 \\
26 \\
22\end{array}$ & $\begin{array}{l}\overline{478} \\
632 \\
501 \\
612\end{array}$ & $\begin{array}{l}\overline{94} \\
83 \\
79 \\
83\end{array}$ & $\begin{array}{r}\overline{17} \\
10 \\
21 \\
8\end{array}$ & $\begin{array}{l}0 \\
0 \\
0 \\
0\end{array}$ \\
\hline
\end{tabular}

* C352 came into oestrus spontaneously when 24 weeks old. Ewer (1968) reported that the first oestrus can occur in females as young as 17 weeks old.

old (Ewer, 1968). Twelve females aged 22 to 24 weeks were treated. Four received sterile saline, four received a single dose of PMSG (5.0 i.u.) followed $56 \mathrm{hr}$ later by HCG $(2 \cdot 5$ i.u.) and the remaining four received two injections of PMSG ( 5.0 and 2.5 i.u., respectively) on successive mornings, followed $32 \mathrm{hr}$ later by HCG $(2 \cdot 5$ i.u. $)$.

All animals injected with hormone produced epithelial cells in the urine for several days, beginning on Days 3 to 6 . Four of these mated-on Days 4 (two animals), 5 and 6 , respectively. No litters were produced. The pouches underwent pre-parturition changes between Days 17 and 19 and became flabby about Day 21.

One control female (C363) mated on Day 7 but did not produce epithelial cells in the urine nor undergo pouch changes during the following 3 weeks. The pouch of a second control (C369) became flabby on Day 11, suggesting that the animal was undergoing an oestrous cycle.

The reproductive organs of six females were examined (Table 3 ). One control (C359) was immature - the uteri were tiny, with sparse, straight uterine 
glands, and the ovaries contained primary follicles only. The other control was pregnant, with blastocysts (diameter approximately $310 \mu$ ) in the uteri.

All experimental females had ovulated. Ovulation had occurred recently in the 9-day animals, for the ovaries contained mature tertiary follicles with chromosomes and a polar body in the ovum and granulosa cells that showed no sign of atresia. One ovum of C353 was located in the oviducal funnel. As many as eleven luteinized follicles were present in each ovary. Animals C360 and G361 had mated but the ova had not been fertilized.

The uteri of all four animals were enlarged, with well-coiled glands and tall gland cells, with basal nuclei. The uterine lumina of C360 and C361 were filled with leucocytes.

\section{DISGUSSION}

The mature, di-oestrous albino mouse can be induced to ovulate after a priming injection of gonadotrophin, followed by an ovulatory injection about $48 \mathrm{hr}$ later. Both PMSG and HCG may be used as priming or ovulatory substances, although the equivalent doses are different for the two functions (Lamond, 1960). Edwards \& Gates (1959) induced superovulation and mating in mature mice with a single injection of PMSG ( 1 or 3 i.u.) followed $40 \mathrm{hr}$ later by HCG ( 2 or 3 i.u.), and found that all females responded in a similar manner, regardless of their stage of the oestrous cycle at the time of injection of PMSG. Ovulation began about $11 \mathrm{hr}$ after injection of HGG and was virtually complete by about $14 \mathrm{hr}$ (Edwards \& Gates, 1959).

Prepuberal laboratory mice were induced to ovulate with two injections of PMSG (2 i.u. and $24 \mathrm{hr}$ later, 1 i.u.), followed $30 \mathrm{hr}$ after the second injection by HCG ( 1 i.u.). The animals mated the following night. The eggs were fertilized and developed but the blastocysts did not implant until progesterone was administered to the animals (Smithberg \& Runner, 1960).

The Virginia opossum (Didelphis virginiana), like $S$. crassicaudata, does not breed well in captivity, some females failing to ovulate, and others having irregular and abnormally long oestrous cycles (Nelsen \& White, 1941). Ovulation was induced in the anoestrous opossum with twice-daily subcutaneous injections of FSH for 4 days, followed by twice-daily injections of FSH plus HCG (Antuitrin-S) for 3 days. Eggs could be recovered from the uteri $24 \mathrm{hr}$ after the last injection (Nelsen \& White, 1941). Nelsen \& Maxwell (1941) treated di-oestrous opossums with FSH and Antuitrin-S according to the above procedure and seven of thirty mated, three producing litters.

The failure of fertilization in $S$. crassicaudata females that mated may have been due to the length of time between mating and ovulation. Most matings occurred on the 3 rd to 6 th days. Fertilization could perhaps be achieved if the females were artificially inseminated on the expected day of ovulation, i.e. about Day 7. Dziuk \& Runner (1960) were able to recover blastocysts from prepuberal laboratory mice that had been artificially inseminated up to $13 \mathrm{hr}$ after ovulation.

Several abnormalities of ovulation were produced by the gonadotrophins. Firstly, the average number of ova released was thirty-one (S.D. 15.8) in ten 
treated females compared with an average of 14.4 (S.D. 4.7) in nine untreated females (Godfrey, unpublished). Superovulation is not advantageous in a marsupial, for no more young can be reared than there are teats in the pouch. Secondly, the number of luteinized follicles was much greater in hormonetreated than in untreated females.

The third and most serious abnormality was the retention of ova in the oviducts. Fertilized and unfertilized marsupial ova (e.g. Setonix didelphis) reach the uterus 1 day after ovulation (Sharman, 1959) and Godfrey (unpublished) recovered two- to four-cell ova from the uteri of two untreated $S$. crassicaudata 2 days after mating. However, ova were retained in the oviducts for as long as 5 days after induced ovulation. Injection of small doses of oestrogen into the recently-ovulated mouse or rabbit causes tube-locking of ova (Whitney \& Burdick, 1936) and retention of ova within the oviducts of $S$. crassicaudata may have been caused by oestrogen released from the many mature follicles.

Further experiments with lower doses of gonadotrophins may elucidate the causes of these abnormalities.

\section{ACKNOWLEDGMENTS}

This research was supported by a grant from the Australian Research Grants Committee to Professor H. G. Andrewartha. We are grateful to Misses P. Dyson and D. Alexander for the care of the animal colony.

\section{REFERENCES}

Dzrux, P. J. \& RunNer, M. N. (1960) Recovery of blastocysts and induction of implantation following artificial insemination of immature mice. F. Reprod. Fert. 1, 321.

Edwards, R. G. \& Gates, A. H. (1959) Timing of the stages of maturation divisions, ovulation, fertilization and first cleavage of eggs of adult mice treated with gonadotrophins. F. Endocr. 18, 292.

EwER, R. F. (1968) A preliminary survey of the behaviour in captivity of the dasyurid marsupial, Sminthopsis crassicaudata (Gould). Z. Tierpsychol. 25, 319.

Godfrey, G. K. (1969) Reproduction in a laboratory colony of the marsupial mouse, Sminthopsis larapinta (Marsupialia-Dasyuridae). Aust. F. Zool. 17, 637.

LAMOND, D. R. (1960) Induction of ovulation in mice with placental gonadotrophins. f. Endocr. 20, 277.

Marlow, B. (1965) Marsupials of Australia. Jacaranda Press, Brisbane.

Martin, P. G. (1965) The potentialities of the fat-tailed marsupial mouse, Sminthopsis crassicaudata (Gould), as a laboratory animal. Aust. F. Zool. 13, 559.

Nelsen, O. E. \& MAxwel. N. (1941) Induced oestrus and mating in the opossum (Didelphis virginiana). Anat. Rec. 81, 105. (Suppl.)

Nelsen, O. E. \& White, E. L. (1941) A method for inducing ovulation in the anoestrous opossum (Didelphis virginiana). Anat. Rec. 81, 529.

Sharman, G. B. (1959) Marsupial reproduction. In: Biogeography and Ecology in Australia. Monographiae biol. 8, 332. Ed. A. Keast. Junk, The Hague.

Sharman, G. B. (1962) The initiation and maintenance of lactation in the marsupial, Trichosurus vulpecula. 7. Endocr. 25, 375.

SmithberG, M. \& RunNer, M. N. (1960) Retention of blastocysts in non-progestational uteri of mice. 7. exp. Zool. 143, 21.

Whitney, R. \& BuRdick, H. O. (1936) Tube-locking of ova by oestrogenic substances. Endocrinology, 20,643 . 